\title{
MISCELÁNEA
}

\section{UN CANTARCILLO TRANSMITIDO POR ANDRÉS BERNÁLDEZ}

Manuel Alvar

El cronista Andrés Bernáldez ha transmitido dos cantarcillos que, si familiares en sus días, nunca se han recogido en las colecciones de nuestra poesía popular. Me refiero a los que se entonaron cuando eran anunciadas las bodas de Isabel con Fernando ${ }^{1}$. En el relato del año 1471 dice el historiador :

Después que se comenzaron las guerras en Castilla entre el rey don Enrique e los caballeros de sus reinos ${ }^{2}$, e antes que el rey don Fernando casase con la reina doña Isabel, se decía un cantar en Castilla que decían las gentes nuevas, a quien la música suele aplacer, a muy buena sonada: Flores de Aragón, dentro en Castilla son: Flores de Aragón dentro en Castilla son. E los niños tomaban pendoncicos chiquitos; y caballeros en cañas, jineteando decían: Pendón de Aragón; pendón de Aragón. E yo le decía e dije más de cinco veces ${ }^{3}$.

El cronista ha dado todos los indicios: eran cantares que entonaban los jóvenes, tenían música y la melodía sonaba bien. Ni más ni menos que otros tantos poemillas como llegaron a los cancioneros musicales. $\mathrm{Y}$ esas flores

1 Historia de los Reyes Católicos don Fernando y doña Isabel, en la "Biblioteca de Autores Españoles", LXX, pág. 574a. El fragmento figura también en las páginas 20-21 de Las memorias del reinado de los Reyes Católicos, que escribía el bachiller Andrés Bernáldez (edic. M. Gómez-Moreno y J. de M. Carriazo). Madrid, 1962.

2 Se refiere a los "bandos y parcialidades que en Castilla ovo entre los cavalleros y comunidades"; el cronista hizo especial referencia a las banderías del duque de $\mathrm{Me}$ dina Sidonia y del marqués de Cádiz.

3 Vid. mi artículo Castilla la preciada en Variedad y unidad del español. Estudios lingüisticos desde la Historia. Madrid, 1969, pág. 41.

LXVIII, $1 .^{\circ}-2 .^{\circ}-10$ 
aragonesas serian las que el Diccionario de Autoridades definía al señalar que "flor: Metaphoricamente significa la parte más escogida y selecta de alguna cosa, como de un reino, provincia, etc.", y pone dos ejemplos que valen a nuestra ocasión: "Después de diez horas de pelea, en que murió la flor de Francia" (Fuenmayor, Vida de San Pio V, f. 65) y "para satisfacerse del daño que en los Gelves había recibido su ejército, muriendo la flor de Castilla" (Colmenares, Hist. Segovia, cap. 36, § 15).

La difusión del cantarcillo no debió ser grande, si nos atenemos a un testimonio indirecto, e incierto por tanto. En El mejor mozo de España, Lope de Vega no echa mano de él, como hubiera podido en algún momento de su obra, y según recurrió a algún romance. Cierto que tampoco escribió la segunda parte de la historia en la que también pudo haberlo incluido. Conjeturas sin otro valor que el serlo. Sin embargo, en 1914, Eduardo Marquina escribió Las flores de Aragón ${ }^{4}$ y allí, en el acto I, cuando don Fernando disfrazado habla a la Princesa Isabel, se dicen estos versos:

Don Fernando. La tarde que, de embajada
salimos para esta tierra,
cantaba una mora un canto
mendigando ante sus puertas;
y era el cantar de la mora
tan hecho a nuestra manera,
que al ir pasando a su lado
le dimos todos moneda...
Recuerdo algunas palabras;
no llegan a diez; son éstas:
"Las flores de Aragón
dentro en Castilla son" 5.

Marquina se inspiró en Bernáldez, por más que no haya dejado constancia de ello. Al final del volumen hay unas notas sobre las obras incluidas en él, pero se silencia cualquier observación sobre ésta. Sólo en una apostilla a El Gran Capitán (pág. 1.355) se habla de Las flores de Aragón en las licencias que el dramaturgo se tomó sobre el tiempo y que nada tienen que ver con nuestro objeto.

- Se puede leer en sus Obras completas, t. II. Madrid, 1944, págs. 829-974.

- Páginas 849-850. Doña Isabel repite el estribillo, "quebrada la voz de una emoción indecible" (pág. 850). La Princesa volverá a recordarlo en la página 859. Mucho después (en el acto IV, pág. 962), se repetirá la evocación de las flores de Aragón. 